\title{
Agent Based Modeling and Simulation of the Olive Fly (Bactrocera Oleae) in Turkey
}

\author{
Simge Baba*, Şebnem Bora* \\ ${ }^{\mathbf{1}}$ Ege Üniversitesi, Mühendislik Fakültesi, Bilgisayar Bölümü, İzmir, Türkiye (ORCID: 0000-0000-0000-0000) \\ ${ }^{2}$ Ege Üniversitesi, Mühendislik Fakültesi, Bilgisayar Bölümü, İzmir, Türkiye (ORCID: 0000-0000-0000-0000) \\ (International Symposium on Multidisciplinary Studies and Innovative Technologies (ISMSIT) 2021 - 21-23 October 2021)
}

(DOI: 10.31590/ejosat.1010632)

ATIF/REFERENCE: Baba, S. \& Bora, Ş. (2020). Agent Based Modeling and Simulation of the Olive Fly (Bactrocera Oleae) in Turkey. European Journal of Science and Technology, (29), 255-258.

\begin{abstract}
In this paper, the relationship of the olive fly with the olive has been closely examined and the life cycle of the olive fly and olive are modeled in the Repast Simphony agent-based simulation environment to show how the population of olive flies changes and how the growing population affects olives. Using data, it has been observed how an olive fly reproduces in a short time and turns into many new generations. Increased olive fly population constitutes a serious threat to the success of control methods used for the damages of olives. In line with the data obtained from this study, olive fly population and damages to olives can be estimated for future years. Olive fly has been determined that the olive fly reduces the yield of the olive tree and it is necessary to combat the olive fly. It is very important to control the olive fly. Therefore, various control methods should be tried. An effective method for increasing the number of olive flies has been investigated. Olive fly numbers were obtained at the end of cultural biological and chemical struggles. In this study, the biological developmental stages of olive fly and olive can be observed. In line with the data obtained from this study, future years and damage to olives can be estimated.
\end{abstract}

Keywords: Agent, agent based modeling, olive, olive fly (bactrocera oleae)

\section{Türkiye'de Zeytin Sineğine (Bactrocera Oleae) Karşı Verilen Mücadelenin Etmen Tabanlı Modellenmesi ve Benzetimi}

Özet

Bu çalışmada, zeytin sineğinin mücadelesi etmen tabanlı modelleme ile gösterilmiştir. Zeytin sineğinin zeytin ile olan ilişkisi yakından incelenmiştir. Zeytin sineğinin ve zeytinin biyolojik gelişim evreleri gözlemlenebilmektedir. Gerçek veriler kullanılarak, kimyasal ve biyolojik mücadelede zeytin sineği populasyonu değişim miktarı ve elde edilen zeytin verimi grafiksel olarak analiz edilebilmektedir. Bir zeytin sineğinin nasıl kısa bir zamanda üreyip çok sayıda yeni jenerasyona dönüştüğü görülmüştür. Artan zeytin sineği popülasyonu, zeytin zararları için kullanılan kontrol yöntemlerinin başarısı için ciddi bir tehdit oluşturmaktadır. Bu çalışmadan elde edilen veriler doğrultusunda gelecek yıllar için zeytin sineği popülasyonu ve zeytine vereceği zararlar tahmin edilebilir. Zeytin sineğinin zeytin ağacının verimini azalttığı ve zeytin sineği ile mücadele edilmesi gerektiği tespit edilmiştir. Zeytin sineğinin kontrolü çok önemlidir. Bu nedenle çeşitli kontrol yöntemleri denenmelidir. Zeytin sineği sayısını artırmak için etkili bir yöntem araştırılmıştır. Kültürel biyolojik ve kimyasal mücadeleler sonucunda zeytin sineği sayıları elde edilmiştir. Bu çalışmada zeytin sineği ve zeytinin biyolojik gelişim aşamaları gözlemlenebilmektedir. Bu çalışmadan elde edilen veriler doğrultusunda gelecek yıllar ve zeytinin zararları tahmin edilebilir.

Anahtar Kelimeler: Etmen, etmen tabanlı modelleme, zeytin, zeytin sineği (bactrocera oleae).

\footnotetext{
Corresponding Author: Ege Üniversitesi, Mühendislik Fakültesi, Bilgisayar Bölümü, İzmir, ORCID: 0000-0000-0000-0000, simge.baba94@hotmail.com sebnemcbora@gmail.com
} 


\section{Introduction}

Olive, olea europaea subsp.cuspidata (Wall.G.Don) Cif.(Ligustrales:Oleaceae), grown in Mediterranean area, is an important agricultural product. Olive is an evergreen tree that can grow up to 10 meters in height, with dense branches, broad crown, and evergreen leaves. It has a wide, curved, tubular trunk. The crown (top) of the tree expands each year, approximately as much as it increases in height. It is a long-lived tree and can live up to 2000 years. Health is of great importance. This purpose is in the foreground. It has an important technical place, which is produced as oil and table. It is widely produced in special Aegean, Marmara and Mediterranean provinces, in Turkey. (Turanli, 2017)

Many living things can harm the olive. One of them, the olive fly (Bactrocera oleae), is the most dangerous of them all. It reduces the productivity of olives. The olive varieties most susceptible to the olive fly are: freckled, memecik, çakır, tomato, quince, ladoelies and gemlik. (Turanli, 2017)

Adults begin to emerge when the soil temperature reaches $10^{\circ} \mathrm{C}$, and the density generally increases from June. Adult olive flies begin to lay their eggs on olives at the end of June. The laid eggs hatch after two days and become larvae. In the olive, the larvae start to grow over time by feeding and thus damage the olives. The larvae that emerge as pupae spend the winter in the soil. When it becomes an adult, it mates and the same cycle is repeated. Thus, it causes the fruits to rot and fall, decrease the amount of olive oil, and partially increase the acidity of the oil. Especially in table olives, the damage of the olive fly is more important. (Turanli, 2017)

In humid and temperate regions, from the end of June to the beginning of July, it can cause significant damage throughout the summer, starting with the pickled Gemlik and Manzanilla varieties and the Ladoelies olive variety for oil. If there is no struggle, it can cause $15-30 \%$ damage, and up to $80 \%$ in epidemic years. (Turanli, 2017)

In the research conducted in the olive groves of Antalya province between 1986-1988, it was determined that the olive fly population was at a very low level in this region, and it was said that the existing natural balance should be preserved. In the research conducted in the olive groves in the Artvin region between 1991-1994, olive flies were found in small quantities. It was also observed that the olive fly did not harm the olives. Although the number of olive flies in Turkey was low in those years, the situation is bad when we look at the number of olive flies in different countries.

In the 2000s, the damage of the olive fly has increased in our country. Therefore, various methods of struggle have been developed. As a result of the negative effects of the chemical control against olive fly on living things, sterile insect release method and efforts to increase olive fly parasitoids in nature appear as alternative methods. As a cultural precaution, it is the cultivation of the soil in winter. Pupae that pass through are cleaned from the soil. In addition, the use of biological control factors within the scope of integrated control studies against olive fly has an important place. Olive fly parasitoid P. concolor is used in biological control by mass production and release to olive groves. By combining this parasitoid with mass trapping, success has been achieved in olive fly control.
In this study, the struggle of the olive fly is shown by agentbased modeling. The relationship of the olive fly with the olive has been closely examined. The subject is observed better with agent-based modeling. The study was programmed in the Repast Symphony 2.1 agent-based simulation environment. It has been observed how an olive fly reproduces in a short time and turns into a large number of new generations. Various methods of struggle have been tried. Biological developmental stages of olive fly and olive can be observed. In line with the data obtained from this study, future years and damage to olives can be estimated.

In this study, besides computer programming knowledge, agricultural and biological field knowledge is needed. For this, the characteristics of olive, its importance in the world and in Turkey, the harvest time of the olive and the planting method of the olive will be explained. The definition of olive fly, its biology, damage to olives and the spread of the pest were simulated.

\section{Material and Method}

Agent-based modeling and simulation (ABMS) is a new approach to modeling systems comprised of autonomous, interacting agents. Computational advances have made possible a growing number of agent-based models across a variety of application domains. Agent-based modeling focuses on the individual active components of a system. This is in contrast to both the more abstract system dynamics approach and the process-oriented discrete event method. With agent-based modeling, active entities known as agents must be identified and their behavior described. They can be people, households, vehicles, equipment, products, or companies, whatever is related to the system. Connections are made between them, environmental variables are set, and simulations run. The global dynamics of the system then emerge from the interactions of many individual behaviors. (Macal ,2009)

This simulation is written in Java language in Repast Simphony 2.1 environment using agent-based simulation method. The reason for choosing this method is that it provides an environment suitable for the working structure of biological systems that occur in nature and provides a better understanding of the biological cycle. According to the scenario: We have an olive field with an area of $1000 \mathrm{~m} 2$. In this field, 30 trees were planted in the form of $5 \mathrm{~m} * 5 \mathrm{~m}$, that is, according to the square shape. Approximately $20 \mathrm{~kg}$ of yield is obtained from an olive tree. According to the calculation, there are approximately 5000 olives in an olive tree. Progress has been made in the program by using these data. Gemlik region is considered as the place where the scenario takes place. Green olives are harvested like September and November, while black olives are harvested after November. Necessary information is given in Table 2.1 to adapt it for the agent-based simulation whose scenario is given.The program starts in June and ends at the end of September. In other words, a period of 90 days passes.

Olive flies breed in June and lay their eggs on small olives on the tree. In the program, the embryo grows by $0.1 \mathrm{~mm}$ per day. Because after 2-3 days, it turns into a larva. The development of the larva is $10-15$ days. When the egg turns into a pupa, it leaves the olive and begins to grow in the soil. Eventually, it becomes an adult. The olive fly can spend the winter in the soil or die. (Rice,2003) 
It can also remain as a pupa in the soil. However, an olive fly can live for an extra year at most. Females die directly after 200 spawns. Male olive flies also die when the probability of survival is less than $95 \%$. Initially the embryo is 0.1 . (Rice,2003) (Economopoulos, 1982)

Table 2.1. The equivalent of the real system in the simulation environment

\begin{tabular}{|l|l|}
\hline Real environment & Representative environment \\
\hline Field area $1000 \mathrm{~m}^{2}$ & 150.000 \\
\hline $0.0006 \mathrm{~m}^{2}$ & 1 cell \\
\hline 1 day number & 1 tick day number \\
\hline Olive, olive fly, parasioid & Agent \\
\hline chance of olive fly surviving & $\% 95$ \\
\hline Average rainfall for 90 days & $22 \mathrm{~mm}$ \\
\hline 90 -day average temperature $\left({ }^{\circ} \mathrm{C}\right)$ & $23.3^{\circ} \mathrm{C}$ \\
\hline 90 -day relative humidity $(\%)$ & $\% 40$ \\
\hline
\end{tabular}

\section{Algorithm:}

1. The number of ticks has been determined as 90 days. In other words, the olive fly will spend 3 months in the olive field.

2. The olive fly goes to one of the neighboring cells randomly and lays its eggs on the olive in that cell.

3. When the olive fly reaches $4-6 \mathrm{~mm}$ in length, it begins to lay eggs. It lays eggs 200 times in its lifetime and dies. Olive fly lives a maximum of one extra year, regardless of gender.

4. Biological states of olive fly:

- Embryo (egg): If the olive fly is between $0.0-0.9 \mathrm{~mm}$

- First (larva): If between 0.9-3.8 mm

- Second (pupae): If between 3.8-4.0 mm

- Adult: If it is between 4-6 mm

If the olive fly is larger than $6 \mathrm{~mm}$, it dies.

5. The egg grows $0.1 \mathrm{~mm}$ with each step. (Bento 2002)(Turanl1,2017) (Pala 2001)

\section{Results and Discussion}

\subsection{Experimental Studies}

a) Initially, the number of adult olive flies is 1000 . Olive fly population size-time graph until step 90 is shown in Figure 3.1. The final number of olive fly is about 1550 .

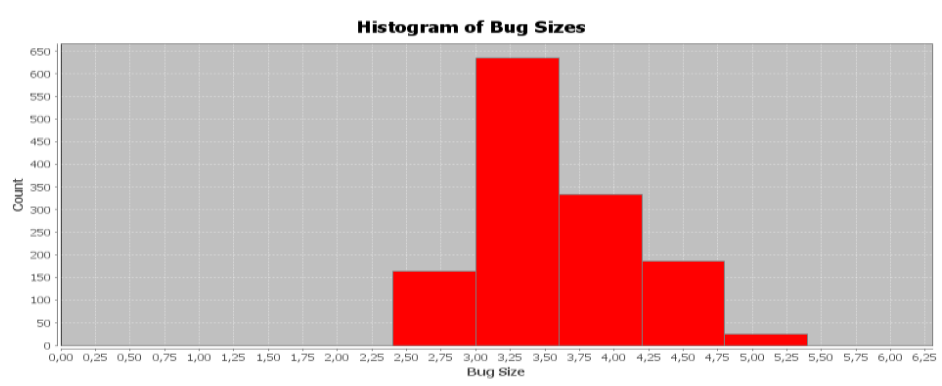

b) Initially, the number of adult olive flies is 2000 . At the beginning of the simulation (Step 0) 2000 olive fly agents were randomly placed in the field to represent the adult olive fly from the winter quarters. Olive fly size histogram of step 90 in Figure 3.2.

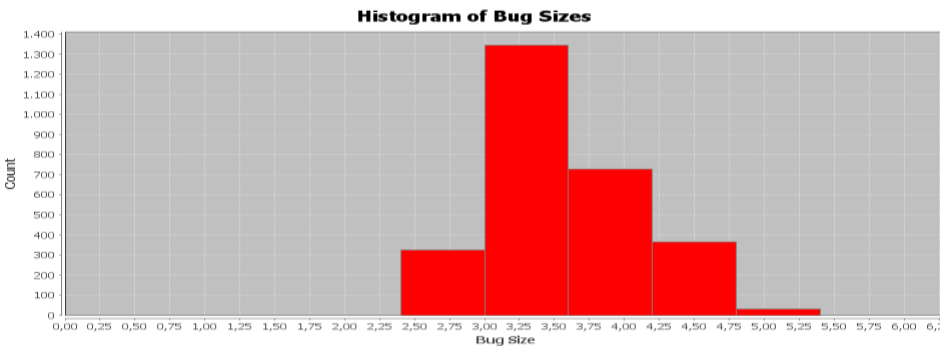

Figure 3.2 Olive fly size histogram at 90th simulation step.

The olive fly population size-time graph until the 90th simulation step is shown in Figure 3.3. The population of olive flies reaches it maximum value at the 42 th time step. The final number of olive fly is about 2880 .

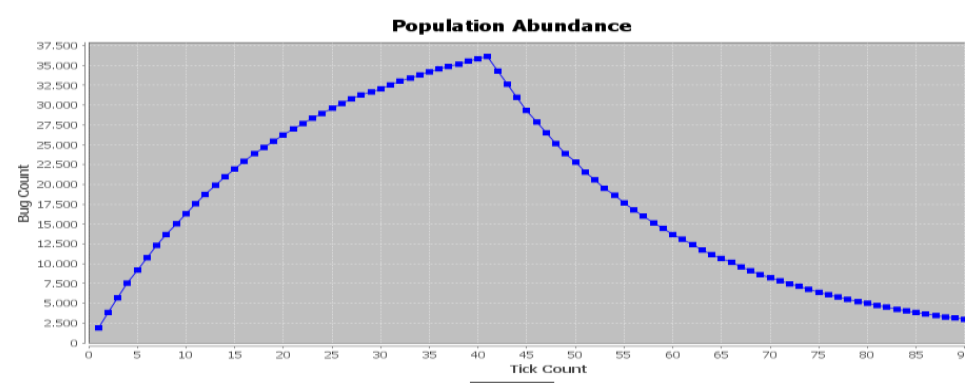

Figure 3.3 Olive fly population size-time plot up to step 90

c) Cultural prevention: Pupa start to be collected with the help of tractor while they are in the soil. In the program, this event was realized as if it was spraying after the Second period. It is not thought that all of them have been cleared in the soil. Olive fly survival probability is reduced to 0.18 after cultural prevention.

The initial number of adult olive flies was determined as 1000. Cultural prevention was carried out after the pupa (second) period of the olive fly. We should think of this process as spraying.

According to the result obtained in the absence of spraying, 1550 olive flies remained in the environment, while the result obtained in the cultural measure was 950. Its effect is around $38 \%$.. If we reduce the probability of individuals to survive after the spraying, the number of olive flies in the last situation may decrease even more.

Figure 3.1 Olive-fly size histogram at 90th simulation step. 


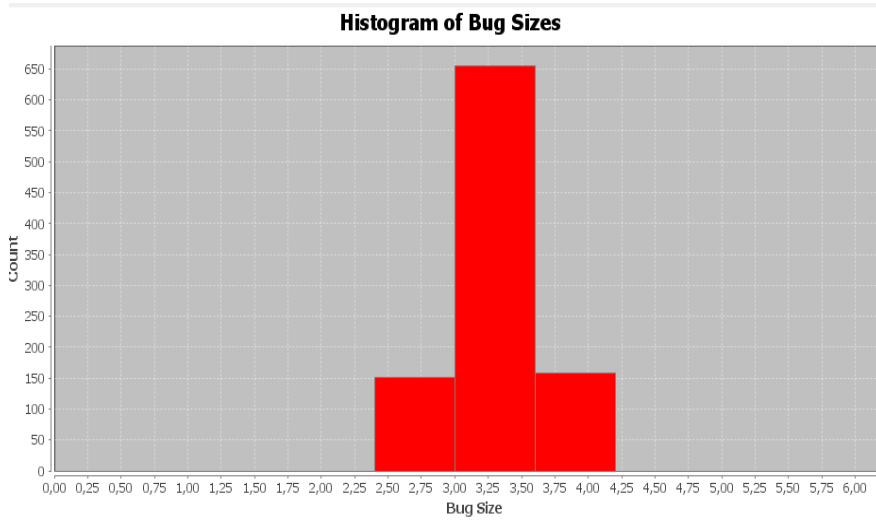

Figure 3.4 Olive fly size histogram at 90th simulation step

\section{Conclusions and Recommendations}

It has been observed how an olive fly reproduces in a short time and turns into a large number of new generations. It has been determined that the olive fly reduces the yield of the olive tree and it is necessary to combat the olive fly. It is very important to control the olive fly. Therefore, various control methods should be tried.

In this study, the biological developmental stages of olive fly and olive can be observed. In line with the data obtained from this study, future years and damage to olives can be estimated.
The fights against the parazoite (the natural enemy of the olive fly) will be included in our biological control studies.

\section{References}

[1] Bento, A., Torres, L., Lopes, J., Sismeiro, R., 2002. A Contribution to the Knowledge of Bactrocera oleae (Gmel)in Tras-Os-Montes Region (Noertheastern Portugal): Phenology, Losses and Control. http://www.actahort.org/books/474/474_111.htm

[2] Economopoulos, A. P., Haniotakis, G. E., Michelakis, S., 1982. Population studies on the olive fruit fly, Dacus oleae (Gmel.) (Dipt.; Tephritidae) in Western Crete. J. Appl. Entomol., 463-476pp.

[3] Macal C. ,North M,2009.Tutarorial On Agent-based Modelling and Simulation

[4] Pala, Y., Nogay, A., Damgacı, E., Altın, M., 2001. Zeytin Bahçelerinde Entegre Mücadele Teknik Talimatı. Tarım ve Köyişleri bakanlığı, Tarımsal Araştırmalar Genel Müdürlüğü, Bitki Sağlığı Araştırmaları Daire Başkanlığ 1 , Ankara, 84 s.

[5] Rice, R.E, Phillips, PA, Stewart-Leslie, J., Sibbert, G.S., 2003. Olive fly populations measured in central and southern California. 122-127pp.

[6] Turanlı ,T, 2017. Gıda Tarım Haycancılık Bakanlığının kitabı Zeytin Entegre Mucadele Teknik Talimatı 18-22. 